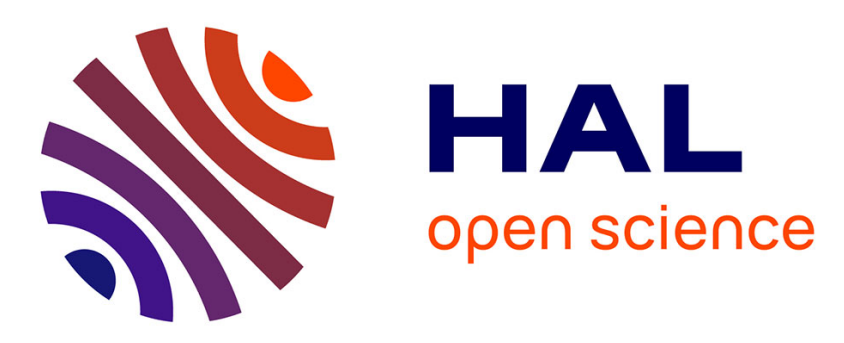

\title{
Aromatic-Based Design of Highly Active and Noncalcemic Vitamin D Receptor Agonists
}

Pranjal Gogoi, Samuel Seoane, Rita Sigüeiro, Thierry Guiberteau, Miguel Maestro, Román Pérez-Fernández, Natacha Rochel, Antonio Mouriño

\section{- To cite this version:}

Pranjal Gogoi, Samuel Seoane, Rita Sigüeiro, Thierry Guiberteau, Miguel Maestro, et al.. AromaticBased Design of Highly Active and Noncalcemic Vitamin D Receptor Agonists. Journal of Medicinal Chemistry, 2018, 61 (11), pp.4928-4937. 10.1021/acs.jmedchem.8b00337 . hal-02383159

\section{HAL Id: hal-02383159 \\ https://hal.science/hal-02383159}

Submitted on 11 Jan 2022

HAL is a multi-disciplinary open access archive for the deposit and dissemination of scientific research documents, whether they are published or not. The documents may come from teaching and research institutions in France or abroad, or from public or private research centers.
L'archive ouverte pluridisciplinaire HAL, est destinée au dépôt et à la diffusion de documents scientifiques de niveau recherche, publiés ou non, émanant des établissements d'enseignement et de recherche français ou étrangers, des laboratoires publics ou privés. 


\title{
Aromatic-Based Design of Highly Active and Noncalcemic Vitamin D Receptor Agonists
}

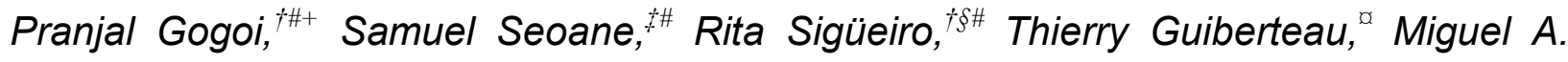 \\ Maestro, ${ }^{\Uparrow}$ Román Pérez-Fernández, ${ }^{* *}$ Natacha Rochel, ${ }^{\S *}$ Antonio Mouriño. ${ }^{\dagger *}$
}

${ }^{\dagger}$ Department of Organic Chemistry, Research Laboratory Ignacio Ribas, University of Santiago de Compostela, Avda. das Ciencias s/n, 15782 Santiago de Compostela, Spain

${ }^{\ddagger}$ Department of Physiology-Center for Research in Molecular Medicine and Chronic Diseases (CIMUS), University of Santiago de Compostela, Avda. Barcelona s/n, 15706 Santiago de Compostela, Spain

${ }^{\S}$ Department of Integrative Structural Biology, IGBMC - Université de Strasbourg, CNRS UMR 7104, INSERM U1258, 67400 Illkirch, France

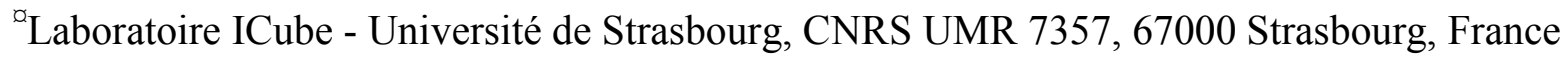

"Department of Chemistry-CICA, University of A Coruña, Campus da Zapateira s/n, 15071 A Coruña, Spain

${ }^{+}$Current address: Chemical Science and Technology Division, CSIR-NEIST, Jorhat, Assam, India

KEYWORDS: active vitamin D analog; calcemia; antiproliferation; crystal structure 


\begin{abstract}
We report the design, synthesis, biological evaluation and structural analysis of a new class of vitamin D analogs that possess an aromatic $m$-phenylene D-ring and an alkyl chain replacing the C-ring. A key feature of the synthetic strategy is a stereoselective Pd-catalyzed construction of the triene system in aqueous medium that allows the rapid preparation of small amounts of VDR ligands for biological screening. Analogs with the shorter (2a) and longer (2d, 2e) side chains attached to the triene system have no calcemic activity. Compound 2a binds to VDR with the same order of magnitude than calcipotriol and oxacalcitriol. It also reduces proliferation in normal and tumor cells similarly to the natural hormone $1 \alpha, 25$-dihydroxyvitamin $\mathrm{D}_{3}$, calcipotriol and oxacalcitriol, suggesting preclinical studies related to hyperproliferative disorders such as psoriasis and cancer.
\end{abstract}




\section{INTRODUCTION}

Increasing synthetic efforts have been directed toward the development of noncalcemic analogs of the natural hormone $1 \alpha, 25$-dihydroxyvitamin $\mathrm{D}_{3}(1,25 \mathrm{D}$, calcitriol, 1, Fig. 1a) for treatment of specific disorders, but only a few of them have found clinical applications. ${ }^{1,2}$ Among these, calcipotriol $^{3}$ and oxacalcitriol (OCT), ${ }^{4}$ two $1,25 \mathrm{D}$-analogs modified at the side chain, have been successfully used for topical treatment of psoriasis, because they are rapidly metabolized before exerting calcemic effects. ${ }^{5}$ Various classic synthetic $1,25 \mathrm{D}$ analogs have been shown to have anti-tumor activities. ${ }^{2}$ Highly active $1,25 \mathrm{D}$-analogs that exert less calcemic activity than the natural hormone by a non rapid metabolism and unknown mechanism have also been developed. The most notable structural features of these compounds include lack of the 19-methylene group, ${ }^{6}$ unsaturation at the side chain or D-ring, ${ }^{7,8}$ 14-epi-configuration, ${ }^{9,10} 3$-epi-configuration, ${ }^{11}$ short nonhydroxylated side chains, ${ }^{12}$ and carboranic side chains. ${ }^{13}$ CD-carboranic and aromatic VDR modulators have also been reported. ${ }^{14,15}$

Recently we described a flexible and efficient convergent synthetic approach for the preparation of vitamin D analogs. ${ }^{16}$ This synthesis has been used to access the natural hormone $1,25 \mathrm{D}^{17}$ and a variety of vitamin D analogs modified at the side-chain, ${ }^{13}$ triene system, ${ }^{18} \mathbf{C}$-ring, ${ }^{19}$ and A-ring, ${ }^{11,20}$ that were required to establish structure-function relationships for the development of active ligands of the VDR with potential therapeutic value. Biological studies on analogs with modified C/D region that comprise C-ring analogs lacking the D-ring, ${ }^{21,22}$ D-ring analogs lacking the C-ring ${ }^{23,24}$ and six-membered D-ring analogs, ${ }^{25,26}$ have demonstrated that the native bicyclic CD-core is not required for biological activity and its alteration might lower the calcemic activity. ${ }^{27}$ 
In a search for vitamin $\mathrm{D}$ analogs that are highly active in the circulation, but with low or negligible calcemic effects, we describe a modification of the reported synthetic approach for rapid and economic access to novel vitamin D analogs 2 (Fig. 1a) and disclose their structures and their biological activities with respect to cell differentiation-proliferation, transactivation and secondary calcemic effects. This novel class of analogs lack the C-ring and the D-ring is replaced by an aromatic ring, which offers flexibility for further chemical functionalization. Some of these analogs are highly active and noncalcemic in comparison to the natural hormone 1,25D. X-ray crystallographic analysis of VDR complexes with analogs 2 revealed their binding mode.

\section{$<$ FIGURE $1>$}

\section{RESULTS and DISCUSSION}

Aromatic-based design of 1,25D analogs. We previously described the successful structurebased design of highly active and superagonist ligands for the VDR. ${ }^{18-20}$ We found that these ligands bind significantly in silico to VDR and adopt an elongate conformation similar to that of the natural hormone with the hydroxyl groups interacting through the same hydrogen bonds. ${ }^{18,19,28}$ These compounds bind to VDR LBD more efficiently than their corresponding derivatives with shorter hydroxylated side chain. On the basis that alteration of the CD-rings lowers the calcemic activity, ${ }^{27}$ we designed the five novel $1,25 \mathrm{D}$ analogs 2 by docking studies into the crystal structure of the hVDR ligand binding domain (LBD)-1,25D complex, ${ }^{29}$ to investigate whether the lack of the $\mathbf{C}$-ring and the presence of a $m$-phenylene ring replacing the D-ring of the natural hormone could serve for the development of potent analogs with improved pharmacological properties, in particular, without the undesired calcemic action. We reasoned 
that the aromatic ring might alter the natural ligand-VDR interactions, thus inducing selective properties. In addition, the aromatic unit allows flexibility to access to a large number of aromatic-substituted analogs.

Docking studies were carried out into the hVDR LBD-1,25D crystal complex ${ }^{29}$ using the GOLD program (Table S1). In all cases, the A-ring and the triene system of the new vitamin D ligands adopt similar positions in comparison with the natural hormone and the A-ring-hydroxyl groups form hydrogen bonds with the same amino acid residues (Fig. 1b and Fig. S1). The alkyl chains attached to $\mathrm{C} 8$ of the triene system adopt different elongated conformations that interact strongly with the protein residues Trp286 and Tyr295. Side-chain length increasing generates additional interactions with other LBP residues such as Val300. To accommodate the C8-alkyl chains, substantial differences are observed in the conformations adopted by the aromatic rings and the main side chain. In ligands $\mathbf{2 a}, \mathbf{2 b}$ and $\mathbf{2 c}$, where the C8-alkyl chains are shorter, the aromatic rings show a parallel orientation with respect to Trp286 and the corresponding hydroxylated side chains adopt extended conformations, where the hydroxyl groups interact optimally by hydrogen bonding with His305 and His397. The aromatic unit of ligands $\mathbf{2 d}$ and $\mathbf{2 e}$, which is attached to the longest C8-alkyl chains, adopts a perpendicular position with respect to Trp286, and the hydroxyl group of the side-chain does not interact with His397 by hydrogen bonding.

Synthesis of compounds 2. The synthetic route to target analogs 2 is described in Scheme 1, and starts with commercially available 3-bromobenzaldehyde (3), which was converted to the key alkyne 7 in $66 \%$ overall yield over 4 steps. The aldehyde 3 was coupled with freshly prepared organozinc reagent $4^{30}$ in the presence of catalytic amounts of tris(dibenzylideneacetone)dipalladium( $(0)$ and tri-tert-butylphosphine in tetrahydrofuran to provide the ester $\mathbf{5}$ in 
good yield. Chain-extension on $\mathbf{5}$ by the method of Corey-Fuchs ${ }^{31}$ utilizing the ylide prepared from zinc, triphenylphosphine and carbon tetrabromide in dichloromethane, gave the vinyl dibromide 6, which was treated with methyllithium in tetrahydrofuran to generate 7 with both the tertiary hydroxyl and the alkyne functionalities in good yield. Protection of the tertiary hydroxyl group of 7 with triethylsilyltrifluoromethanesulfonate and triethylamine in dichloromethane afforded alkyne 8. This four-step synthetic strategy allows flexibility for variations at the side chain and aromatic ring. Next goal was the introduction of the five different alkyl groups corresponding to target analogs 2a-e. This was accomplished in good yield by exposure of $\mathbf{8}$ to the cuprate generated from the alkylmagnesium bromide, copper(I) iodide and lithium chloride in tetrahydrofuran followed by trapping of the resulting alkenyl copper intermediate with trimethylsilyl chloride in hexamethylphosphoramide. The resulting alkenylsilanes 9a-e were then treated with $\mathrm{N}$-iodosuccinimide in dichloromethane to afford stereoselectively the corresponding iodides 10a-e in good yield, which were converted to the desired upper boronates 11a-e by Miyaura's modified method ${ }^{16,32}$ utilizing bis(pinacolato)diboron and potasium acetate in the presence of catalytic [1,1'-bis(diphenylphosphino)ferrocene $]$ dichloropalladium(II) in dimethylsulfoxide. With the upper fragment in hand, the stage was set for the final convergent formation of the triene system. Pd-catalyzed ring-closure of the enol triflate $\mathbf{1 2}^{16}$ (1.1 equiv) and a subsequent Suzuki-Miyaura reaction with boronate 11a-e (1 equiv) in aqueous medium provided, ${ }^{16}$ after deprotection, the desired vitamin D analogs 2a-e (15-37\% overall yield from 3-bromobenzaldehyde, 8 steps).

$<$ SCHEME 1 $>$ 
Functional activity of compounds 2a-e. It is noteworthy that all des-C-analogs bind significantly to VDR despite the fact that the natural CD-ring is replaced by a linear short sidechain attached to $\mathrm{C} 8$ and a $m$-disubstituted benzene ring (Table 1; Fig. S2). These interesting results prompted us to study their biological activity. As in case of $1,25 \mathrm{D}$, all compounds strongly induce differentiation in human keratinocyte cells and increase p21, p27 and p53 protein expression, well-known 1,25D target genes (Table 1; Fig. 2a-b). The new ligands show similar anti-proliferative activity in both bi- and three-dimensional analyses than $1,25 \mathrm{D}$ in human normal keratinocytes and breast, prostate, and ovarian cancer cell lines (Table 1; Fig. S3a-f), where 2a, with shortest chain at $\mathrm{C} 8$, is the most active. The CYP24A1 (24-hydroxylase)transcriptional activity induced by all compounds correlates with VDR affinity, with $\mathbf{2 a}$ being the most potent one, as compared to $1,25 \mathrm{D}$ (Table 1; Fig S4a). These results confirm that the natural CD-ring is not required for genomic activity. Notably, in comparison with vehicle-treated mice, none of compounds 2a-e induce hypercalcemia (Table 1; Fig S4b). Furthermore, high doses of compound 2a did not increase calcium levels in mice sera (Fig. 3a).

$<$ Table 1 $>$

$<$ Figure $2>$

Numerous studies have associated 1,25D with anti-tumoral properties. ${ }^{33-35}$ VDR is present in breast cancer cells, ${ }^{36}$ and a recent study has shown that VDR expression should be considered for breast cancer treatment. ${ }^{37}$ However, hypercalcemia is an undesirable side effect of the natural hormone when used at pharmacological doses. ${ }^{38}$ The remarkable lack of calcemic activity of compound 2a, together with its significant VDR binding and transcriptional activity led us to study its antitumor properties. Severe combined immunodeficiency (SCID) mice injected with 
the highly aggressive human breast cancer MDA-MB-231 cell line and treated with compound 2a significantly reduced tumor growth as compared controls (Fig. 3b-c). Notably, a significant increase in overall survival of $\mathbf{2 a}$ treated-mice without signs of toxicity in the liver and kidney as well as no significant weight loss was also observed (Fig. 3d; Fig. S5a-b). To further study the therapeutic relevance of compound $\mathbf{2 a}$ on the tumorigenesis process, we focus on its effects on cancer stem cells. The role of cancer stem cells in cancer initiation, progression, drug resistance, and relapse $\mathrm{e}^{39}$ is well known. As shown in Fig. 3e-g, a significant decrease in both growth and number of mammospheres was observed after treatment of cancer stem cells (CSC)-like with $100 \mathrm{nM}$ of $\mathbf{2 a}$ as compared to control. Altogether, our data indicate that compound $\mathbf{2 a}$ acts on both cancer cells and cancer stem cells, suggesting that it could be a therapeutic option in breast cancer.

$<$ Figure $3>$

Structural features of VDR interaction with compounds 2. The docking data were substantially corroborated by the crystal structures of $\mathbf{2 a - 2 e}$ bound to the LBD of zebrafish-VDR [(zVDR) LBD] in the presence of SRC-2 coactivator peptide, solved at a resolution of $2.5 \AA$, $2.7 \AA, 2.6 \AA, 2.3 \AA$ and $2.75 \AA$ for zVDR-2a, -2b, -2c, $\mathbf{- 2 d}$ and -2e complexes, respectively (see supporting information and Table S2 for details). All complexes display the canonical agonist conformation of previously reported structures of VDR bound to agonist ligands with helix H12 folded in the agonistic position. ${ }^{40,41}$ The ligands are buried in the predominantly hydrophobic pocket and adopt the same orientation as $1,25 \mathrm{D}$ (Fig. 4). The alkyl chains attached to $\mathrm{C} 8$ of the triene system and the aromatic ring occupy the space filled by the CD-rings of the natural $1,25 \mathrm{D}$ ligand. Some flexibility of the terminal methyl group of the alkyl chain was observed for most of 
the ligands as indicated by the weak density of the corresponding atoms (Fig. S6). A minor discrepancy between modeling and X-ray data is observed for the conformation of the aromatic ring that is identical and parallel to zTrp314 (hTrp286 in docking) in all crystallographic complexes (Fig. 4a). Indeed, the VDR LBP accommodates the different variants of the C8-alkyl central chain through different conformations of the $\mathrm{C} 8$-alkyl and aromatic terminal side chains, together with rearrangement of the protein. The three hydroxyl groups of the compounds form H-bonds with a pair of residues for each $\mathrm{OH}$ group, similarly to 1,25D (Fig. 4b-f).

The main differences in the interactions of the VDR-2a-e complexes compared to the VDR$1,25 \mathrm{D}$ complex are observed in the region of the central part (aromatic moiety and C8-alkyl chain) and terminal aliphatic side chain (Fig. 5 and Fig. S7). Interestingly, analogs 2 form tighter interactions with zlle299(hIle268), a specific interaction already observed for some low-calcemic analog. ${ }^{42} \mathrm{zTrp} 314$ (hTrp286) does not interact with the aromatic moiety of all compounds, but interacts with the $\mathrm{C} 8$-alkyl chains. Increasing the length of the $\mathrm{C} 8$-alkyl side chain in $2 \mathrm{e}$ leads to the formation of additional interactions as with zMet254 (hMet226) and zVal328 (hVal300) (Fig. 5). However, these additional contacts of the heptyl-chain of $2 \mathbf{e}$ induce a different positioning of the terminal aliphatic side chain and reorientation of some nearby amino acids to maintain interactions. In all complexes, the terminal aliphatic side chains form similar interactions and notably a stronger contact with zPhe448 (hPhe422) in H12 compared to 1,25D. In comparison to bis and tri-aromatic derivatives, ${ }^{43}$ the analogs 2 better mimic the conformation of $1,25 \mathrm{D}$ and maintain the hydrophobic interaction of $1,25 \mathrm{D}$.

Overall the crystal structures of VDR complexes reveal that analogs 2 form similar interactions as $1,25 \mathrm{D}$, stabilizing the agonistic conformation of VDR. 


\section{$<$ Figure 4>}

\section{CONCLUSION}

This paper reports a series of new analogs which possess a $m$-phenylene D-ring and an alkyl chain replacing the $\mathbf{C}$-ring. These analogs are clearly no calcemic, but are as active as the nature hormone 1,25D. Indeed, hybrid analogs with the shorter (2a) and longer (2d, 2e) side chains attached to the triene system have no calcemic activity. The compounds are similarly accommodated by the VDR LBD as $1,25 \mathrm{D}$. The molecular basis for their transcriptional activity is the conservation of the hydrogen binding network and hydrophobic interactions of the natural ligand. While some specific interactions are observed, the relationship among the differential interactions mediated by the ligands compared to $1,25 \mathrm{D}$ and non-calcemic activities of the ligands remains to be elucidated. Compound 2a reduces proliferation in normal and tumor cells similarly to the natural hormone without increasing serum calcium levels. We tested its in vivo efficacy in a xenograft model of breast cancer. In the aggressive MDA-MB-231 cells implanted in SCID mice, compound 2a had high efficacy for tumor growth inhibition and overall survival.

In summary, this study provides important structure-activity relationship information on novel aromatic-based vitamin D analogs. Their properties, combined with the low calcemic actions, make these analogs promising agents for clinical treatment of hyperproliferative disorders including cancer. 


\section{EXPERIMENTAL SECTION}

Docking procedure. The receptor and the ligands were used as MOL2 files. Energy minimization was not performed on the protein. Compounds $\mathbf{2 a - e}$ were built using the Builder module of the InsightII molecular modeling $\operatorname{program}^{44}$ and the crystal structure of $1,25 \mathrm{D}$, obtained from the complex of 1,25D-hVDR LBD (protein data bank code: 1DB1). ${ }^{29}$ The initial conformation of the ligand was energy-minimized using the Discover program and cvff forcefield (5000-step, steepest descent, in vacuum at $300 \mathrm{~K}) .{ }^{45}$ Finally, docking studies to predict the affinity of the ligands for the VDR were carried out using the GOLD program (version Suite 5.2). A modified crystal structure (addition of hydrogen, reconstituted gaps and corrected His tautomers) of the complex between 1,25D-hVDR LBD was chosen as protein. The Ligand Binding Pocket of the LBD was defined as Binding Site with the automatic active-site detection on, and the radius was set to $10 \AA$. Ligands were docked in 25 independent genetic algorithm (GA) runs, for each of which a maximum of 125000 GA operations were performed on a single population of 100 individuals. Operator weights for crossover, mutation, and migration in the entry box were used as default parameters $(95,95$, and 10 , respectively), as well as the hydrogen bonding $(4.0 \AA)$ and van der Waals $(2.5 \AA)$ parameters. The "flip ring corners" flag was switched off, while all the other flags were on. CHEMPLP was used as a scoring function and GoldScore as a re-scoring function. The best three solutions were obtained with an associated score. The values obtained are shown in the Table S1. The punctuations were compared with those obtained for 1,25D. In all cases, the fitness scores for the new ligands were lower than those obtained for $1,25 \mathrm{D}$.

Cell Culture. Human breast adenocarcinoma MCF-7 and MDA-MB-231 cells, human prostate adenocarcinoma PC3 cells, human ovary adenocarcinoma SKOV-3 cells, and human 
keratinocytes HaCaT cells were obtained from ATCC-LGC (Barcelona, Spain). Cells were tested and authenticated according to microscopic morphology, growth curve analysis, and mycoplasma detection according to the ECACC cell line verification test recommendations. Cells were grown in DMEM media supplemented with $10 \%$ FBS, $100 \mathrm{U} / \mathrm{mL}$ penicillin, $100 \mathrm{U} / \mathrm{mL}$ streptomycin, and $2 \mathrm{mM}$ L-glutamine (all from Invitrogen, Paisley, UK), in air- $\mathrm{CO}_{2}$ (95:5) atmosphere a $37^{\circ} \mathrm{C}$. Confluent cells were washed twice with PBS and harvested by a brief incubation with trypsin-EDTA solution (Sigma-Aldrich, St. Louis, USA) in PBS. Treatments with $1,25 \mathrm{D}$, or compounds $\mathbf{2 a - e}$ were carried out using medium supplemented with charcoaltreated FCS to remove liposoluble hormones. Control cells were treated with ethanol as vehicle.

Cell proliferation analyses. Two-dimensional (2D) cell proliferation was carried out in MCF-7, PC3, SKOV-3 and HaCaT cells using 3-(4,5-dimethylthiazol-2-yl)-2,5-diphenyltetrazolium bromide (MTT) assay as previously described. ${ }^{46}$ Cells were treated with $1,25 \mathrm{D}$ or compounds 2a-e at $10^{-8}$ or $10^{-7} \mathrm{M}$ for 48 hours. Three-dimensional (3D) cell cultures were performed as previously described. Cells were then treated with $10^{-7} \mathrm{M}$ of $1,25 \mathrm{D}$ and 2a-e for 5 days. Phase contrast photographs three-dimensional cultures were taken with a Olympus DP72 camera. Quantitation of the sphere diameters was performed manually by tracing a straight line across the diameter of the sphere and scoring its value as relative units. Three-dimensional Cancer Stem Cell culture (3D-CSC) was performed using a commercial assay Cell2Sphere ${ }^{\mathrm{TM}}$ (Stemtek Therapeutics, Bilbao, Spain) containing the human breast adenocarcinoma MDA-MB-436 cell line enriched with CSCs under manufacturer's instructions. Ethanol (as control) or compound 2a $\left(10^{-8}\right.$ or $\left.10^{-7} \mathrm{M}\right)$ were added for 5 days and quantitation of sphere number and diameter was performed as described above. 
Human VDR Binding Assay. Binding affinity to VDR was evaluated using a 1,25D assay kit under manufacturer conditions (Polarscreen Vitamin D receptor competitor assay, Invitrogen) as previously described. ${ }^{19}$ All 2a-e compounds were evaluated within the range from $10^{-11}$ to $10^{-5} \mathrm{M} . \mathrm{IC}_{50}$ values were calculated using average of measured values. Activity of each compound is also shown as percentage, in which the activity of the $1,25 \mathrm{D}$ natural hormone was normalized to $100 \%$.

Luciferase Reporter Assays. Luciferase reporter assays were performed as previously described. ${ }^{19}$ Transfections were performed using $1 \mu \mathrm{g}$ of pCYP24A1-Luc plasmid (kindly provided by Dr. Aranda). This vector encoding the luciferase gene under control of a consensus vitamin D response element (24-hydroxylase promoter, CYP24A1). After incubation for $24 \mathrm{~h}$ the medium was replaced by each compound $(1,25 \mathrm{D}$ or $\mathbf{2 a - e})$ at concentrations $10^{-11}$ to $10^{-6} \mathrm{M}$. Bioluminescence images was acquired with the In Vivo Imaging System (IVIS, Caliper Life Sciences, Alameda, USA), and total photon counts were quantified using Living Image software (Caliper Life Sciences). The $\mathrm{EC}_{50}$ values are derived from dose-response curves and represent the analogue concentration capable of increasing the luciferase activity by $50 \%$. The luciferase activity ratio is the average ratio of the $\mathrm{EC}_{50}$ for the analogue to the $1,25 \mathrm{D}$ value at the same dose.

Crystallization and Structure Determination. cDNA encoding zVDR LBD (156-453 AA) was cloned into pET28b vector to generate $N$-terminal His-tag fusion proteins. Purification was carried out as previously described, including metal affinity chromatography and gel filtration. ${ }^{47}$ The protein was concentrated using Amicon ultra-30 (Millipore) to 3-7 $\mathrm{mg} / \mathrm{ml}$ and incubated with a two-fold excess of ligand and a three-fold excess of the coactivator SRC-2 peptide (686KHKILHRLLQDSS-698). Crystals were obtained in $50 \mathrm{mM}$ Bis-Tris pH 6.5, $1.6 \mathrm{M}$ lithium 
sulfate and $50 \mathrm{mM}$ magnesium sulfate. Protein crystals were mounted in a fiber loop and flashcooled under a nitrogen flux after cryo-protection with $20 \%$ glycerol. Data collection from a single frozen crystal was performed at $100 \mathrm{~K}$ on the PX1 beamline at SOLEIL (France). The raw data were processed and scaled with the HKL2000 program suite. ${ }^{48}$ The crystals belong to the space group $\mathrm{P}_{5} 22$, with one LBD complex per asymmetric unit. The structure was solved and refined using BUSTER, ${ }^{49}$ Phenix ${ }^{50}$ and iterative model building using COOT ${ }^{51}$ Crystallographic refinement statistics are presented in Table S2. All structural figures were prepared using PyMOL (www.pymol.org/).

Synthesis. General procedures and spectroscopic data $\left({ }^{1} \mathrm{H},{ }^{13} \mathrm{C}-\mathrm{NMR}, \mathrm{HRMS}, \mathrm{IR},[\alpha]\right)$ for all compounds are described detailed in supporting information.

Ethyl 6-(3-formylphenyl)hexanoate (5). Aldehyde 3 (1.5 g, $8.1 \mathrm{mmol}, 1$ equiv) was dissolved in THF (5 mL). $\mathrm{Pd}_{2}(\mathrm{dba})_{3}\left(0.074 \mathrm{~g}, 0.08 \mathrm{mmol}, 0.01\right.$ equiv) and $t \mathrm{Bu}_{3} \mathrm{P}(0.160 \mathrm{~mL}, 0.160 \mathrm{mmol}$, 0.02 equiv, $1 \mathrm{M}$ ) were successively added. A solution of the organozinc compound $4^{30}$ (see supporting information) in THF ( $\sim 1.5$ equiv) was added and the reaction mixture was stirred at 23 ${ }^{\circ} \mathrm{C}$ for $30 \mathrm{~min}$. The reaction was quenched with saturated $\mathrm{NH}_{4} \mathrm{Cl}(10 \mathrm{~mL})$. The mixture was extracted with $\mathrm{Et}_{2} \mathrm{O}(3 \times 20 \mathrm{~mL})$. The combined organic fractions were dried, filtered and concentrated in vacuo. The residue was purified by flash chromatography (2\% EtOAc/hexanes) to afford ester 5 [1.95 g, $7.86 \mathrm{mmol}, 97 \%, R_{f}=0.45$ (20\% EtOAc/hexanes), colorless oil].

Ethyl 6-[3-(2,2-dibromovinyl)phenyl] hexanoate (6). A mixture of $\mathrm{Ph}_{3} \mathrm{P}$ (3.96 g, $15.1 \mathrm{mmol}$, 2.5 equiv) and $\mathrm{Zn}\left(0.987 \mathrm{~g}, 15.1 \mathrm{mmol}, 2.5\right.$ equiv) in $\mathrm{CH}_{2} \mathrm{Cl}_{2}(40 \mathrm{~mL})$ was stirred at $23{ }^{\circ} \mathrm{C}$ for $15 \mathrm{~min}$ and then cooled to $0{ }^{\circ} \mathrm{C}$. After $5 \mathrm{~min}, \mathrm{CBr}_{4}(5 \mathrm{~g}, 15.1 \mathrm{mmol}, 2.5$ equiv) was added. The 
reaction mixture was stirred at $0{ }^{\circ} \mathrm{C}$ for $1 \mathrm{~h}$ and at $23{ }^{\circ} \mathrm{C}$ for $1.5 \mathrm{~h}$. A solution of 5 (1.5 g, 6.04 mmol, 1 equiv) in $\mathrm{CH}_{2} \mathrm{Cl}_{2}(10 \mathrm{~mL})$ was added via cannula. The mixture was stirred at $23{ }^{\circ} \mathrm{C}$ for $1 \mathrm{~h}$ and filtered through a pad of celite (the solids were washed with $\mathrm{Et}_{2} \mathrm{O}$ ). The combined organic layers were concentrated in vacuo and the residue was purified by flash chromatography $\left(2 \%\right.$ EtOAc/hexanes) to afford dibromide $6\left[2.24 \mathrm{~g}, 5.54 \mathrm{mmol}, 92 \%, R_{f}=0.68(20 \%\right.$ EtOAc/hexanes), brown oil]. 7-(3-Ethynylphenyl)-2-methylheptan-2-ol (7). A solution of $\mathrm{MeLi}$ in $\mathrm{Et}_{2} \mathrm{O}$ (19.8 mL, 29.7 mmol, 6 equiv, 1.5M) was added to a $-78^{\circ} \mathrm{C}$ cooled solution of 6 ( $2 \mathrm{~g}, 4.95 \mathrm{mmol}, 1$ equiv) in THF $(30 \mathrm{~mL})$. The reaction mixture was allowed to reach $23{ }^{\circ} \mathrm{C}$. The reaction was quenched with sat $\mathrm{NH}_{4} \mathrm{Cl}(20 \mathrm{~mL})$. The mixture was extracted with $\mathrm{Et}_{2} \mathrm{O}(3 \times 20 \mathrm{~mL})$. The combined organic fractions were dried, filtered and concentrated in vacuo. The residue was purified by flash chromatography (5\% EtOAc/hexanes) to afford the alkyne $7 \mathbf{a}\left[0.89 \mathrm{~g}, 3.86 \mathrm{mmol}, 78 \%, R_{f}=0.3\right.$ (20\% EtOAc/hexanes), colorless oil].

7-(3-Ethynylphenyl)-2-methylheptan-2-triethylsilyl ether (8). TESOTf (2.34 mL, $10.33 \mathrm{mmol}$, 1.5 equiv) and dry $\mathrm{Et}_{3} \mathrm{~N}\left(2.86 \mathrm{~mL}, 20.66 \mathrm{mmol}, 3\right.$ equiv) were successively added to a $-78^{\circ} \mathrm{C}$ cooled solution of compound 7 (1.58 g, $6.89 \mathrm{mmol}, 1$ equiv) in $\mathrm{CH}_{2} \mathrm{Cl}_{2}(30 \mathrm{~mL})$. The mixture was stirred for $3 \mathrm{~h}$. The reaction was quenched with sat $\mathrm{NH}_{4} \mathrm{Cl}(20 \mathrm{~mL})$. The mixture was extracted with $\mathrm{Et}_{2} \mathrm{O}(3 \times 30 \mathrm{~mL})$. The combined organic fractions were dried, filtered and concentrated in vacuo. The residue was purified by flash chromatography (hexanes) to afford alkyne 8 [2.25 g, $6.53 \mathrm{mmol}, 95 \%, R_{f}=0.4$ (1\% EtOAc/hexanes), colorless oil].

(E)-2-Methyl-7-\{3-[1-(trimethylsilyl)but-1-en-2-yl]phenyl\}heptan-2-triethylsilyl ether (9a). A mixture of anhydrous $\mathrm{LiCl}(0.177 \mathrm{~g}, 4.18 \mathrm{mmol}, 4.8$ equiv) and $\mathrm{CuI}$ (0.206 g, $2.08 \mathrm{mmol}$, 2.4 equiv) was dried in a reaction tube at $120^{\circ} \mathrm{C}$ for $3 \mathrm{~h}$ under vacuum. The mixture was allowed 
to reach $23{ }^{\circ} \mathrm{C}$. THF $(3 \mathrm{~mL})$ was added and the resulting mixture was stirred at $23{ }^{\circ} \mathrm{C}$ for $30 \mathrm{~min}$. The homogeneous mixture was cooled to $-60{ }^{\circ} \mathrm{C}$ and stirred for $5 \mathrm{~min}$. A solution of EtMgBr in THF (1.4 mL, $4.18 \mathrm{mmol}, 4.8$ equiv, 3M) was added dropwise and the mixture was stirred at $-60{ }^{\circ} \mathrm{C}$ for $1 \mathrm{~h}$. Then, a solution of alkyne $8(0.3 \mathrm{~g}, 0.87 \mathrm{mmol}, 1$ equiv) and HMPA $(0.7 \mathrm{~mL})$ in THF (5 mL) was added via cannula. After 5 min, a mixture of HMPA $(0.3 \mathrm{~mL})$ and freshly distilled TMSCl $(0.53 \mathrm{~mL}, 4.18 \mathrm{mmol}, 4.8$ equiv) were successively added. The reaction mixture was allowed to reach $23{ }^{\circ} \mathrm{C}$ for $7 \mathrm{~h}$ and then poured into sat $\mathrm{NH}_{4} \mathrm{Cl}$ $(15 \mathrm{~mL})$. The solution was extracted with $\mathrm{Et}_{2} \mathrm{O}(4 \times 20 \mathrm{~mL})$. The combined organic fractions were dried, filtered and concentrated in vacuo. The residue was purified by flash chromatography (hexanes) to afford vinylsilane 9a $\left[0.309 \mathrm{~g}, 0.69 \mathrm{mmol}, 79 \%, R_{f}=0.7\right.$ (1\% EtOAc/hexanes), colorless oil].

(E)-7-[3-(1-Iodobut-1-en-2-yl)phenyl]-2-methylheptan-2-triethylsilyl ether (10a). $N$-Iodosuccinimide (0.151 g, $0.67 \mathrm{mmol}, 1$ equiv) was added to a $-45^{\circ} \mathrm{C}$ cooled solution of vinylsilane 9a $(0.3 \mathrm{~g}$, $0.67 \mathrm{mmol}, 1$ equiv) in $\mathrm{CH}_{2} \mathrm{Cl}_{2}(20 \mathrm{~mL})$. The mixture was stirred for $3 \mathrm{~h}$. The reaction was quenched with sat $\mathrm{Na}_{2} \mathrm{~S}_{2} \mathrm{O}_{3}(20 \mathrm{~mL})$. The mixture was allowed to reach $23{ }^{\circ} \mathrm{C}$ and extracted with $\mathrm{CH}_{2} \mathrm{Cl}_{2}(3 \times 15 \mathrm{~mL})$. The combined organic layers were dried, filtered and concentrated in vacuo. The residue was purified by flash chromatography (hexanes) to afford vinyl iodide 10a [0.331 g, $0.66 \mathrm{mmol}, 99 \%, R_{f}=0.7$ (1\% EtOAc/hexanes), light yellow oil].

(E)-2-Methyl-7-\{3-[1-(4,4,5,5-tetramethyl-1,3,2-dioxaborolan-2-yl]but-1-en-2-yl\}phenyl)heptan2-triethylsilyl ether (11a). $\mathrm{PdCl}_{2}(\mathrm{dppf}) \cdot \mathrm{CH}_{2} \mathrm{Cl}_{2}$ (0.0155 g, $0.019 \mathrm{mmol}, 0.03$ equiv), KOAc (0.188 g, $1.92 \mathrm{mmol}, 3$ equiv, dried in vacuo at $120{ }^{\circ} \mathrm{C}$ for $2 \mathrm{~h}$ ) and bis(pinacolato)diboron (0.195 g, $0.77 \mathrm{mmol}, 1.2$ equiv) were successively added to a solution of vinyl iodide $\mathbf{1 0 a}$ (0.32 g, $0.64 \mathrm{mmol}, 1$ equiv) in DMSO $(3 \mathrm{~mL})$. The reaction mixture was stirred at $80{ }^{\circ} \mathrm{C}$ for $1 \mathrm{~h}$ 
and then allowed to reach $23{ }^{\circ} \mathrm{C}$. Water $(10 \mathrm{~mL})$ was added and the mixture was extracted with $\mathrm{Et}_{2} \mathrm{O}(3 \times 10 \mathrm{~mL})$. The combined organic fractions were dried, filtered and concentrated in vacuo. The residue was purified by flash chromatography (1\% EtOAc/hexanes) to afford vinyl boronic ester $11 \mathrm{a}\left[0.227 \mathrm{~g}, 0.45 \mathrm{mmol}, 71 \%, R_{f}=0.57\right.$ (3\% EtOAc/hexanes), light brown oil].

(1R,3S,Z)-5-\{(E)-3-[3-(6-Hydroxy-6-methylheptyl)phenyl]pent-2-en-1-ylidene\}-4methylenecyclohexane-1,3-diol (2a). Aqueous $\mathrm{K}_{3} \mathrm{PO}_{4}(3 \mathrm{~mL}, 2 \mathrm{M})$ and $\mathrm{PdCl}_{2}\left(\mathrm{PPh}_{3}\right)_{2}(0.007 \mathrm{~g}$, $0.01 \mathrm{mmol}, 0.05$ equiv) were successively added to a solution of boronate $11 \mathrm{a}(0.1 \mathrm{~g}, 0.2 \mathrm{mmol}$, 1 equiv) and enol-triflate $12(0.14 \mathrm{~g}, 0.233 \mathrm{mmol}, 1.17$ equiv) in THF (10 mL). The reaction mixture was vigorously stirred at $23{ }^{\circ} \mathrm{C}$ for $1.5 \mathrm{~h}$ and then diluted with $\mathrm{H}_{2} \mathrm{O}(5 \mathrm{~mL})$. The mixture was extracted with $\mathrm{Et}_{2} \mathrm{O}(3 \times 10 \mathrm{~mL})$. The combined organic layers were dried, filtered and concentrated in vacuo. The residue was purified by flash chromatography $\left(1 \% \mathrm{Et}_{2} \mathrm{O} /\right.$ hexanes $)$ to afford the protected compound which was dissolved in THF $(5 \mathrm{~mL})$. A solution of TBAF in THF (1.2 mL, $1.2 \mathrm{mmol}, 6$ equiv, $1 \mathrm{M}$ ) was added. The mixture was stirred at $23{ }^{\circ} \mathrm{C}$ for $24 \mathrm{~h}$ and then diluted with sat $\mathrm{NH}_{4} \mathrm{Cl}(5 \mathrm{~mL})$. The mixture was extracted with EtOAc $(5 \times 10 \mathrm{~mL})$. The combined organic layers were dried, filtered and concentrated in vacuo. The residue was purified by flash chromatography (70\% EtOAc/hexanes) to afford $\mathbf{2 a}[0.053 \mathrm{~g}, 0.133 \mathrm{mmol}, 67 \%$, $R_{f}=0.4(90 \%$ EtOAc/hexanes), colorless oil], which was further purified by HPLC (22\% $i \mathrm{PrOH} /$ hexanes $) .[\alpha]_{\mathrm{D}}{ }^{25}=+19.1^{\mathrm{o}}(c=1.2$ in EtOH $)$.

\author{
ASSOCIATED CONTENT \\ Accession Code. The atomic coordinates and structure factors have been deposited in the Protein \\ Data Bank, Research Collaboratory for Structural Bioinformatics, Rutgers University, New
}


Brunswick, New Jersey, with entry code 6FOD (compound 2a), 6FO9 (compound 2b), 6FO7 (compound 2c), 6FO8 (compound 2d) and 6FOB (compound 2e). Authors will release the atomic coordinates and experimental data upon article publication.

Supporting Information. The Supporting Information is available free of charge on the ACS Publications website at DOI: 10.1021/acs.jmedchem.xxxx.

Additional supplemental figures, synthetic procedures and characterization data for compounds along with protocols for cell culture, MTT metabolization, human VDR binding affinity, luciferase reporter assays, Western blot assays and animal studies, crystallization assays and refinement of the crystals can be found in SI appendix. Each analog reported as a novel compound in this study (2a, 2b, 2c, 2d and 2e) present a single sharp peaks on HPLC (Phenomenex Luna $5 \mu$ Silica(2) 100A, $250 \times 21.2 \mathrm{~mm}$, normal phase; isocratic mode; $i \mathrm{PrOH} /$ hexanes). HPLC analysis was used to determine the purity $(>95 \%)$ of the vitamin D analogues.

\author{
AUTHOR INFORMATION \\ Corresponding Authors \\ *E-mail: roman.perez.fernandez@usc.es \\ *E-mail: rochel@igbmc.fr \\ *E-mail: antonio.mourino@usc.es
}

Author Contributions

P.G., S.S., R.S., T.G., N.R. conducted experiments; M.A.M, R.P.F., N.R., A.M. designed experiments; all authors contributed to the writing of the paper. 
\# These authors contributed equally.

Notes

The authors declare no competing financial interest.

\title{
ACKNOWLEDGMENTS
}

We thank the Spanish Ministry of Science and Innovation (SAF2010-15291, FEDER to AM), Ministry of Economy and Competitiveness (SAF2015-69221-R, MINECO/FEDER to RP-F), and Xunta de Galicia (GPC2014/001). The work was also supported by grant ANR-13-BSV80024-01 (N.R.) from ANR and institutional funds (N.R.) from Instruct-ERIC for support and the use of resources of the French Infrastructure for Integrated Structural Biology. We thank CESGA for the computing time. RS thanks Xunta de Galicia for a Postdoctoral Fellowship (Plan I2C ano 2012, modalidade A). The authors would like to thank the staff of Proxima 1 at SOLEIL for assistance in using the beamlines and Alastair McEwen (IGBMC) for help in X-ray data collections.

\begin{abstract}
ABBREVIATIONS
1,25D, 1 $\alpha, 25$-dihydroxyvitamin $\mathrm{D}_{3}$; VDR, vitamin $\mathrm{D}$ receptor; LBD, ligand binding domain.
\end{abstract}

\section{REFERENCES}

1 Plum, L. A.; DeLuca, H. F. Vitamin D, disease and therapeutic opportunities. Nat. Rev. Drug Discovery 2010, 9, 941-955.

2 Leyssens, C.; Verlinden, L.; Verstuyf, A. The future of vitamin D analogs. Front. Physiol. 2014, 5, 1-18. 
3 Binderup, L.; Binderup, E.; Godfredsen, W. O. Development of new vitamin D analogs. In Vitamin D; Feldman, D., Glorieux, F. H., Pike, J. W., Eds.; Academic Press: San Diego, CA, 1997; Vol.61, pp 1027-1041.

4 Kubodera, N.; Sato, K.; Nishii, Y. Characteristics of 22-oxacalcitriol (OCT) and 2ß-(3hydroxypropoxy)-calcitriol (ED-71). In Vitamin D; Feldman, D., Glorieux, F. H., Pike, J. W., Eds.; Academic Press: San Diego, CA, 1997; Vol.61, pp 1071-1086.

5 G. Jones. Analog metabolism. In Vitamin D; Feldman, D., Glorieux, F. H., Pike, J. W., Eds.; Academic Press: San Diego, CA, 1997; Vol. 61, pp 973-994.

6 Slatopolsky, E.; Finch, J.; Ritter, C.; Denda, M.; Morrissey, J.; Brown, A.; DeLuca, H. F. A new analog of calcitriol, 19-nor-1,25-(OH) $)_{2} \mathrm{D}_{2}$, suppresses parathyroid hormone secretion in uremic rats in the absence of hypercalcemia. Am. J. Kidney Dis. 1995, 26, 852-860.

7 Uskokovic, M. R.; Studzinski, G. P.; Reddy, G. S. The 16-ene vitamin D analogs. Vitamin D, eds Feldman D, Glorieux FH, Pike JW (Academic, New York), 1997, 62, 1045.

8 Kensler, T. W.; Dolan, P. M.; Gange, S. J.; Lee, J. K.; X Wang, Q.; Posner, G. H. Conceptually new deltanoids (vitamin D analogs) inhibit skin tumorigenesis. Carcinogenesis 2000, $21,1341-1345$.

9 Verlinden, L.; Verstuyf, A.; Van Camp, M.; Marcelis, S.; Sabbe, K.; Zhao, X. Y.; De Clercq, P.; Vandewalle, M.; Bouillon, R. Two novel 14-epi-analogues of 1,25dihydroxyvitamin $\mathrm{D}_{3}$ inhibit the growth of human breast cancer cells in vitro and in vivo. Cancer Res. 2000, 60, 2673-2679.

10 Ma, Y.; Yu, W. D.; Hidalgo, A. A. ; Luo, W.; Delansorne, R.; Johnson, C. S.; Trump, D. L. Inecalcitol, an analog of $1,25 \mathrm{D}_{3}$ displays enhanced antitumor activity through the induction of apopotosis in a squamous cell carcinoma model system. Cell Cycle 2013, 12, 743-752. 
11 Molnar, F.; Sigüeiro, R.; Sato, Y.; Araujo, C.; Schuste, I.; Antony, P.; Peluso, J.; Muller, C.; Mouriño, A.; Moras, D.; Rochel, N. $1 \alpha, 25(\mathrm{OH})_{2}$-epi-vitamin $\mathrm{D}_{3}$, a natural physiological metabolite of vitamin $\mathrm{D}_{3}$ : its synthesis, biological activity and crystal structure with its receptor. PLoS ONE, 2011, 6, e18124.

12 Plum, L. A.; Prahl, J. M.; Ma, X.; Sicinski, R. R.; Gowlugari, S.; Clagett-Dame, M.; DeLuca, H. F. Biologically active noncalcemic analogs of $1 \alpha, 25$-dihydroxyvitamin D with an abbreviated side chain containing no hydroxyl. Proc. Natl. Acad. Sci. USA, 2004, 101, 6900-6904.

13 Otero, R.; Seoane, S.; Sigüeiro, R.; Belorusova, A. Y.; Maestro, M. A.; Pérez-Fernández, R.; Rochel, N.; Mouriño, A. Carborane-based design of a potente vitamin D receptor agonist. Chem. Sci. 2016, 7, 1033-1037.

14 Yamada, S.; Makishima, M. Structure-activity relationship of nonsecosteroidal vitamin D receptor modulators. Trends Pharmacol. Sci. 2014, 35, 324-337.

15 Ma, Y.; Khalifa, B.; Yee, Y. K.; Lu, J.; Memezawa, A.; Savkur, R. S.; Yamamoto, Y.; Chintalacharuvu, R. S.; Yamaoka, K.; Stayrook, K. R.; Bramlett, K. S.; Zeng, Q. Q.;Chandrasekhar, S.; Yu, X. P.; Linebarger, J. H.; Iturria, S. J.; Burris, T. P.; Kato, S.; Chin, W. W.; Nagpal, S. Identification and characterization of noncalcemic, tissue-selective, nonsecosteroidal vitamin D receptor modulators. J. Clin. Invest. 2006, 116, 892-904.

16 Gogoi, P.; Sigüeiro, R.; Eduardo, S; Mouriño, A. An expeditious route to $1 \alpha, 25-$ dihydroxyvitamin $\mathrm{D}_{3}$ and its analogues by an aqueous tandem palladium-catalyzed A-ring closure and Suzuki coupling to the C/D unit. Chem. Eur. J. 2010, 16, 1432-1435.

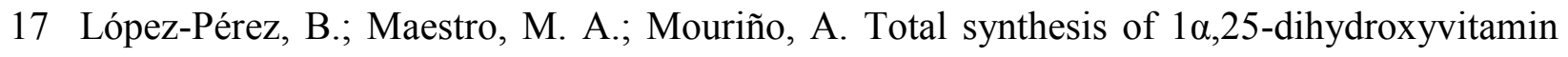
$\mathrm{D}_{3}$ (calcitriol) through a Si-assisted allylic substitution. Chem. Comm. 2017, 53, 8144-8147. 
18 Sokolowska, S.; Carballa, D.; Seoane, S.; Pérez-Fernández, R.; Mouriño, A.; Sicinski, R. R. Synthesis and biological activity of two C-7 methyl analogues of vitamin D. J. Org. Chem. 2015, $80,165-173$.

19 Carballa, D. M.; Seoane, S.; Zacconi, F.; Pérez, X.; Rumbo, A., Alvarez-Díaz, S.; Larriba, M. J.; Pérez-Fernández, R.; Muñoz, A.; Maestro, M.; Mouriño, A.; Torneiro, M. Synthesis and biological evaluation of $1 \alpha, 25$-dihydroxyvitamin $\mathrm{D}_{3}$ analogues with a long side chain at C12 and short C17 side chains. J. Med. Chem. 2012, 55, 8642-8656.

20 Antony, P.; Sigüeiro, R.; Huet, T.; Sato, Y.; Ramalanjaona, N.; Rodrigues, L. C.; Mouriño, A.; Moras, D.; Rochel, N. Structure-function relationships and crystal structures of the vitamin D receptor bound $2 \alpha$-methyl-(20S,23S)- and $2 \alpha$-methyl-(20S,23R)-epoxymethano1a,25-dihydroxyvitamin $\mathrm{D}_{3} . J$. Med. Chem. 2010, 53, 1159-1171.

21 Zhu, G. D.; Chen, Y. J.; Zhou, X. M.; Vandewalle, M.; De Clercq, P. J. Synthesis of CDring modified 1 1 ,25-dihydroxy vitamin D analogues: C-ring analogues. Bioorg. Med. Chem. Lett. 1996, 6, 1703-1708.

22 Zhou, X. M.; Zhu, G. D.; Van Haver, D.; Vandewalle, M.; De Clercq, P. J.; Verstuyf, A.; Bouillon, R. Synthesis, biological activity, and conformational analysis of four seco-D15,19-bisnor-1 $\alpha, 25$-dihydroxyvitamin D analogues, diastereomeric at C17 and C20. J. Med. Chem. 1999, 42, 3539-3556.

23 Verstuyf, A.; Verlinden, L.; Van Etten, E.; Shi, L.; Wu, Y.; D’Halleweyn, C.; Van Haver, D.; Zhu, G. D.; Chen, Y. J.; Zhou, X.; Haussler, M. R.; De Clercq, P.; Vandewalle, M.; Van Baelen, H.; Mathieu, C.; Bouillon, R. Biological activity of CD-ring modified 1 1 ,25dihydroxyvitamin D analogues: C-ring and five-membered D-ring analogues. J. Bone Min. Res. 2000, 15, 237-252. 
24 Yong, W.; Ling, S.; D’Halleweyn, C.; Van Haver, D.; De Clercq, P.; Vandewalle, M.; Bouillon, R.; Verstuyf, A. Synthesis of CD-ring modified 1 1,,25-dihydroxy vitamin D analogues: five-membered D-ring analogues. Bioorg. Med. Chem. Lett. 1977, 7, 923-928.

25 Linclau, B.; De Clercq, P.; Vandewalle, M.; Bouillon, R.; Verstuyf, A. The Synthesis of CDring modified 1 1 ,25-dihydroxy vitamin D analogues: Six-membered D-ring analogues I. Bioorg. Med. Chem. Lett., 1977, 7, 1461-1464.

26 Vrielynck, F.; Van Haver, D.; Vandewalle, M.; Verlinden, L.;Verstuyf, A.; Bouillon, R.; Croce, G.; DeClercq, P. Development of analogues of 1 1, 25 -dihydroxyvitamin D3 with biased side-chain orientation: C20 methylated des-C,D-homo analogues. Eur. J. Org. Chem. 2009, 1720-1737.

27 Eelen, G.; Verlinden, L.; Bouillon, R.; De Clercq, P.; Muñoz, A.; Verstuyf, A. CD-ring modified vitamin $\mathrm{D}_{3}$ analogs and their superagonistic action. J. Steroid. Biochem. Mol. Biol. 2010, 121, 417-419.

28 Hourai, S.; Rodrigues, L. C.; Antony, P.; Reina-San-Martin, B.; Ciesielski, F.; Magnier, B. C.; Schoonjans, K.; Mouriño, A.; Rochel, N.; Moras, D. Structure-based design of a superagonist ligandfor the vitamin D nuclear receptor. Chem. Biol. 2008, 15, 383-392.

29 Rochel, N.; Wurtz, J. M.; Mitschler, A.; Klaholz, B.; Moras, D. The crystal structure of the nuclear receptor for vitamin D bound to its natural ligand. Mol. Cell 2000, 5, 173-179.

30 Krasovskiy, A.; Malakhov, V.; Gavryushin, A.; Knochel, P. Efficient synthesis of functionalized organozinc compounds by the direct insertion of zinc into organic iodides and bromides. Angew Chem. Int. Ed. 2006, 45, 6040-6044

31 Corey, E. J.; Fuchs, P. L. A synthetic method for formyl $\rightarrow$ ethynyl conversion $\left(\mathrm{RCHO} \rightarrow \mathrm{RC} \equiv \mathrm{CH}\right.$ or $\left.\mathrm{RC} \equiv \mathrm{CR}^{\prime}\right)$. Tetrahedron Lett. 1972, 13, 3769-3772. 
32 Ishiyama, T.; Murata, T.; Miyaura, M. Palladium(0)-catalyzed cross-coupling reaction of alkoxydiboron with haloarenes: a direct procedure for arylboronic esters. J. Org. Chem. 1995, $60,7508-7510$.

33 Deeb, K. K.; Trump D. L.; Johnson, C. S. Vitamin D signalling pathways in cancer: potential for anticancer therapeutics. Nat. Rev. Cancer 2007, 7, 684-700.

34 Feldman, D.; Krishnan, A. V.; Swami, S.; Giovannucci, E.; Feldman, B. J. The role of vitamin D in reducing cancer risk and progression. Nat. Rev. Cancer 2014, 14, 342-357.

35 Ma, Y.; Trump D. L.; Johnson, C. S. Vitamin D in combination cancer treatment. J. Cancer 2010, $1:$ 101-107.

36 Buras, R. R.; Schumaker, L. M.; Davood, F.; Brenner, R. V.; Shabahang, M.; Nauta, R. J.; Evans, S. R. Vitamin D receptors in breast cancer cells. Breast Cancer Res. Treat. 1994, 31, 191-202.

37 Santagata, S.; Thakkar, A.; Ergonul, A.; Wang, B.; Woo, T.; Hu, R.; Harrell, J. C.; McNamara, G.; Schwede, M.; Culhane, A. C.; Kindelberger, D.; Rodig, S.; Richardson, A.; Schnitt, S. J.; Tamimi, R. M.; Ince, T. A. Taxonomy of breast cancer based on normal cell phenotype predicts outcome. J. Clin. Invest. 2014, 124, 859-870.

38 Liu, S.; Dontu, G.; Wicha, M. S. Mammary stem cells, self-renewal pathways, and carcinogenesis. Breast Cancer Res. 2005, 7, 86-95.

39 Yang, F.; Xu, J.; Tang, L.; Guan, X. Breast cancer stem cell: the roles and therapeutic implications. Cell Mol. Life Sci. 2017, 74, 951-966.

40 Belorusova, A. Y.; Rochel, N. Structural studies of vitamin D nuclear receptor ligandbinding properties. Vitam. Horm. 2016, 100, 83-116. 
41 Eelen, G.; Verlinden, L.; Bouillon, R.; De Clercq, P.; Muñoz, A.; Verstuyf, A. CD-ring modified vitamin $\mathrm{D}_{3}$ analogs and their superagonistic action. J. Steroid. Biochem. Mol. Biol. 2010, 121, 417-419.

42 Eelen, G., Verlinden, L., Rochel, N., Claessens, F., De Clercq, P., Vandewalle, M., Tocchini-Valentini, G., Moras, D., Bouillon, R., Verstuyf, A. Superagonistic action of 14epi-analogs of 1,25-dihydroxyvitamin D explained by vitamin D receptor-coactivator interaction. Mol Pharmacol. 2005, 67, 1566-1573.

43 Ciesielski, F.; Sato, Y.; Chebaro, Y.; Moras, D.; Dejaegere, A.; Rochel, N. Structural basis for the accommodation of bis- and tris-aromatic derivatives in vitamin D nuclear receptor. $J$. Med. Chem. 2012, 55, 8440-8849.

44 InsightII, Discover and Builder are trademarked software of Accelrys Inc., San Diego, CA

45 Dauber-Osguthorpe, P.; Roberts, V. A.; Osguthorpe, D. J.; Wolff, J.; Genest, M.; Hagler, A. T. Structure and energetics of ligand binding to proteins: E. coli dihydrofolate reductasetrimethoprim, a drug-receptor system. Proteins: Structure, Function and Genetics 1998, 4, $31-47$.

46 Seoane, S.; Arias, E.; Sigüeiro, R.; Sendon-Lago, J.; Martínez-Ordóñez, A.; Castelao, E.; Eiró, N; García-Caballero, T.; Macías, M.; López-López, R.; Maestro, M.; Vizoso, F.; Mouriño, A.; Pérez-Fernández, R. Pit-1 inhibits BRCA1 and sensitizes human breast tumors to cisplatin and vitamin D treatment. Oncotarget 2015, 6, 14456-14471.

47 Belorusova, A. Y.; Eberhardt, J.; Potier, N.; Stote, R. H.; Dejaegere, A.; Rochel, N. Structural insights into the molecular mechanism of vitamin D receptor activation by 
lithocholic acid involving a new mode of ligand recognition. J. Med. Chem. 2014, 57, 47104719.

48 Otwinowski, Z.; Minor, W. Processing of X-ray diffraction data collected in oscillation mode. Method Enzymol. 1997, 276, 307-326.

49 Bricogne, G.; Blanc, E.; Brandl, M.; Flensburg, C.; Keller, P.; Paciorek, W.; Roversi, P.; Sharff, A; Smart, O. S.; Vonrhein, C.; Womack, T. O. BUSTER version 2.11.2. Cambridge, United Kingdom: Global Phasing Ltd 2011.

50 Adams, P. D.; Afonine, P. V.; Bunkoczi, G.; Chen, V. B.; Davis, I. W.; Echols, N.; Headd, J. J.; Hung, L. W.; Kapral, G. J.; Grosse-Kunstleve, R. W.; McCoy, A. J., Moriarty, N. W.; Oeffner, R.; Read, R. J.; Richardson, D. C.; Richardson, J. S; Terwilliger, T. C; Zwart, P. H. PHENIX: a comprehensive Python-based system for macromolecular structure solution. Acta Crystallogr. D 2010, 66, 213-221.

51 Emsley, P.; Cowtan, K. Coot: model-building tools for molecular graphics. Acta Crystallogr. D 2004, 60, 2126-2132. 


\section{Figures Legend}

Figure 1. Aromatic-based design of 1,25D analogs. (a) Structures of 1,25D and the analogs $2 \mathbf{a}-\mathbf{e}$. (b) Superimposition of ligands 2 from docking analysis [2a (green), 2b (blue), 2c (pink), 2d (yellow), 2e (orange)] in the VDR Ligand Binding Pocket with 1,25D (white).

Scheme 1. Synthesis of the analogs 2a-e.

Figure 2. Differentiation and Western blot of vitamin D targets. (a) Differentiation activity in human HaCaT keratinocyte cells treated with $100 \mathrm{nM}$ of 1,25D and 2a-e compounds for 48 hours. (b) MCF-7 cells were treated with $10^{-9}$ to $10^{-7} \mathrm{M}$ of $1,25 \mathrm{D}$ and 2 a-e compounds for 48 hours and then a Western blot was carried out to evaluate p21, p27 and p53 expression. Expression values were obtained by densitometry analyses.

Figure 3. Biological effects of compound 2a. (a) Calcemic activity in mice after 21 days of treatment every other day with vehicle, $1,25 \mathrm{D}$ and compound $\mathbf{2 a}$. (b) SCID mice were subcutaneously injected with MDA-MB-231-luc cells. Ten days later (day 0 of treatment), mice were split up into 2 groups and injected intraperitoneally (i.p.) with the compound $\mathbf{2 a}(1 \mu \mathrm{g} / \mathrm{kg}$ weight, dissolved in sesame oil). The control group was treated with vehicle (sesame oil). Tumor growth was monitored every 7 days from day 10 (0 day of treatment) until day 28 using in Vivo Imaging System. (c) Representative image of mice described in b. Panel in c indicates bioluminescence intensity ( $\mathrm{PF}=$ Photon flux). (d) Animals were treated as described in (b) until day 60 to calculate overall survival. (e) Three-dimensional Cancer Stem Cell culture (3D-CSC) was performed in human breast adenocarcinoma MDAMB-436 cells enriched with CSCs and treated with ethanol or compound $2 \mathrm{a}\left(10^{-8}\right.$ or $\left.10^{-7} \mathrm{M}\right)$ for 5 days. Sphere growth and number of $3 \mathrm{D}$ cultures was quantified and represented in (f) and (g) Error bars represent standard deviation (SD).

Figure 4. X-ray crystal structures of zVDR LBD complexes with 2a-e. (a) Superposition of 2a, 2b, 2c, 2d and 2e. (b) Hydrogen bonds formed by $\mathbf{2 a}$ are shown by red dotted lines. (c) Hydrogen bonds formed by $\mathbf{2 b}$. (d) Hydrogen bonds formed by 2c. (e) Hydrogen bonds formed by $\mathbf{2 d}$. (f) Hydrogen bonds formed by 2e. Ligands 2a-e are superimposed with 1,25D (grey).

Figure 5. (a) Interactions of $\mathbf{2 a}$ with VDR residues within $4 \AA$ distance. Residues interacting with the $\mathbf{A}$ - and seco-B-rings are colored and labelled in cyan, residues interacting with the central part of the ligand are colored and labelled in green and those interacting with the terminal aliphatic side chain in grey. (b) Interactions of 2e with VDR residues within $4 \AA$ distance. Same color for the residues as in Figure 4a. (c) Overlay of the crystal structures of zVDR-2a and zVDR-2e. Residues interacting with the central part and terminal side chain of the compounds 
are shown. The heptyl central group of $2 \mathbf{e}$ induces some conformational changes of some side chains and a different positioning of the terminal side chain.

Table 1. Two- (2D) and three-(3D) dimensional cellular proliferation (expressed as percentage \pm $\mathrm{SD}$ with respect to vehicle treated cells) of the human breast adenocarcinoma MCF-7, the human prostate adenocarcinoma PC-3, the human ovarian cancer SKOV-3, and the human keratinocyte $\mathrm{HaCaT}$ cell lines after culture for $48 \mathrm{~h}$ (2D) and 5 days (3D) with $100 \mathrm{nM}$ of 1,25D and the 2a-2e compounds. Transcriptional activity is expressed as $\mathrm{EC}_{50}$ molar range, and as percentage of the $\mathrm{EC}_{50} \mathrm{M}$ mean with respect to $1,25 \mathrm{D}(100 \%)$. Serum calcium levels (mean $\pm \mathrm{SD}$ ) in mice treated every other day for 21 days with 1,25D and the $\mathbf{2 a - 2 e}$ compounds $(0.3 \mu \mathrm{g} / \mathrm{kg}$ weight, $\mathrm{n}=5$ per group). VDR binding of the $1,25 \mathrm{D}$ and the $\mathbf{2 a - 2 e}$ compounds expressed as $\mathrm{IC}_{50} \mathrm{M}$ range, and as percentage of the $\mathrm{IC}_{50} \mathrm{M}$ mean with respect to $1,25 \mathrm{D}$. 


\section{FIGURES and SCHEMES}

\section{Figure 1}
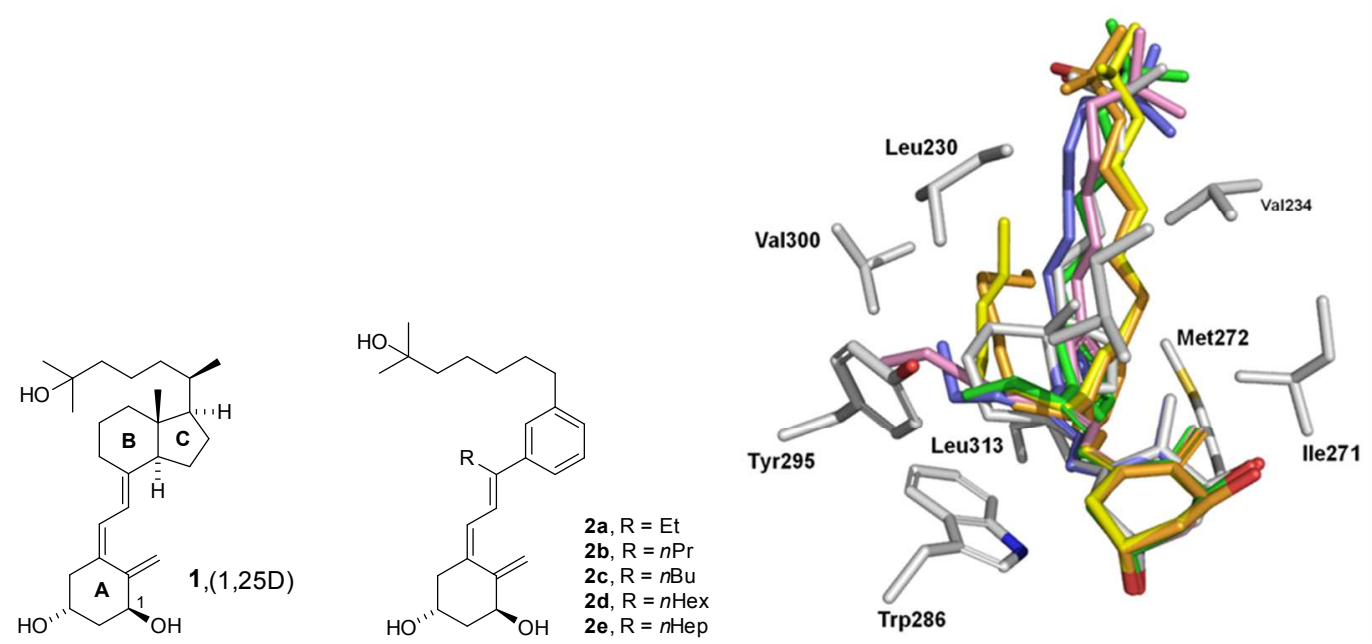

\section{Scheme 1}
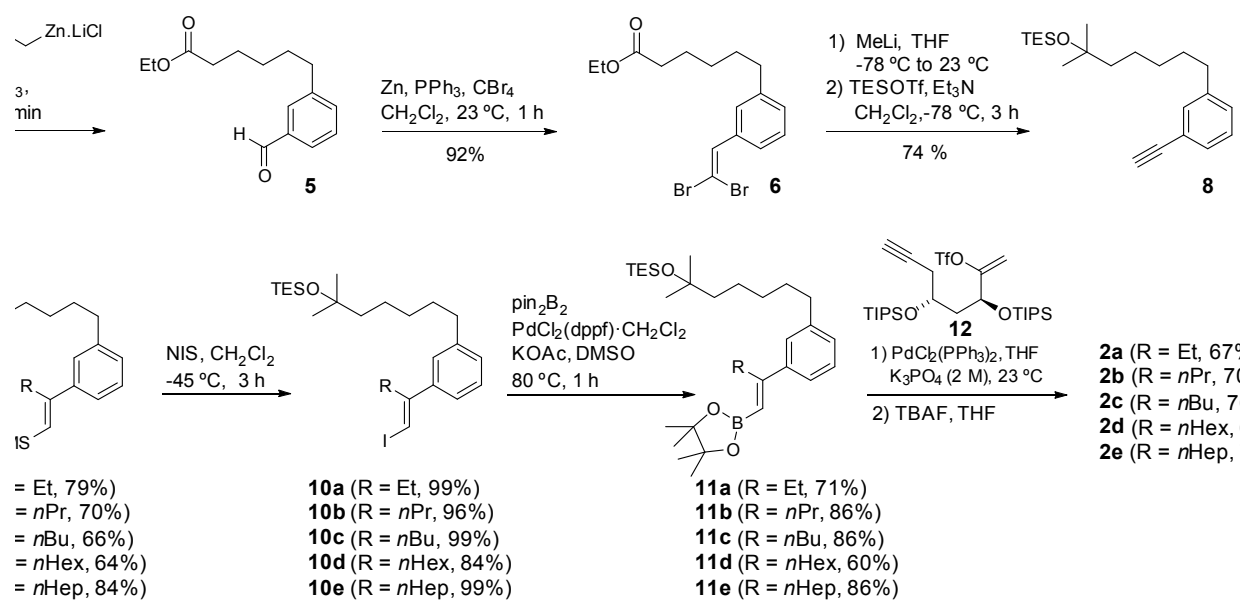

2a $(\mathrm{R}=\mathrm{Et}, 67 \%)$

2b $(\mathrm{R}=n \operatorname{Pr}, 70 \%)$

2c $(\mathrm{R}=n \mathrm{Bu}, 76 \%)$

2d $(\mathrm{R}=n \mathrm{Hex}, 68 \%)$

2e $(\mathrm{R}=n \mathrm{Hep}, 79 \%)$

$10 \mathrm{~d}(\mathrm{R}=n \mathrm{Hex}, 84 \%)$
$10 \mathrm{e}(\mathrm{R}=n \mathrm{Hep}, 99 \%)$

$1 \mathrm{~d}(\mathrm{R}=n \mathrm{Hex}, 60 \%)$

$=n \mathrm{Hep}, 84 \%$ ) 


\section{Figure 2}

$\mathbf{a}$

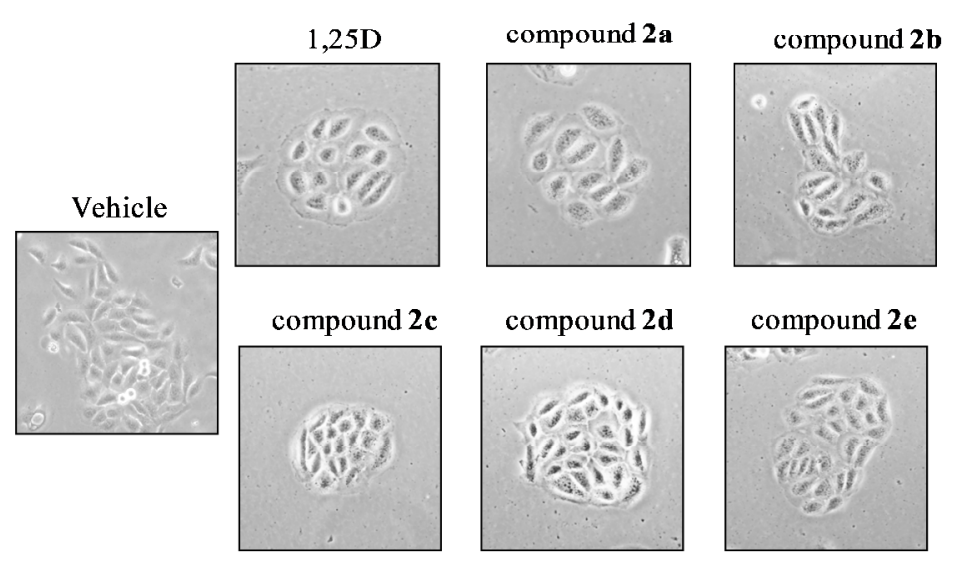

b

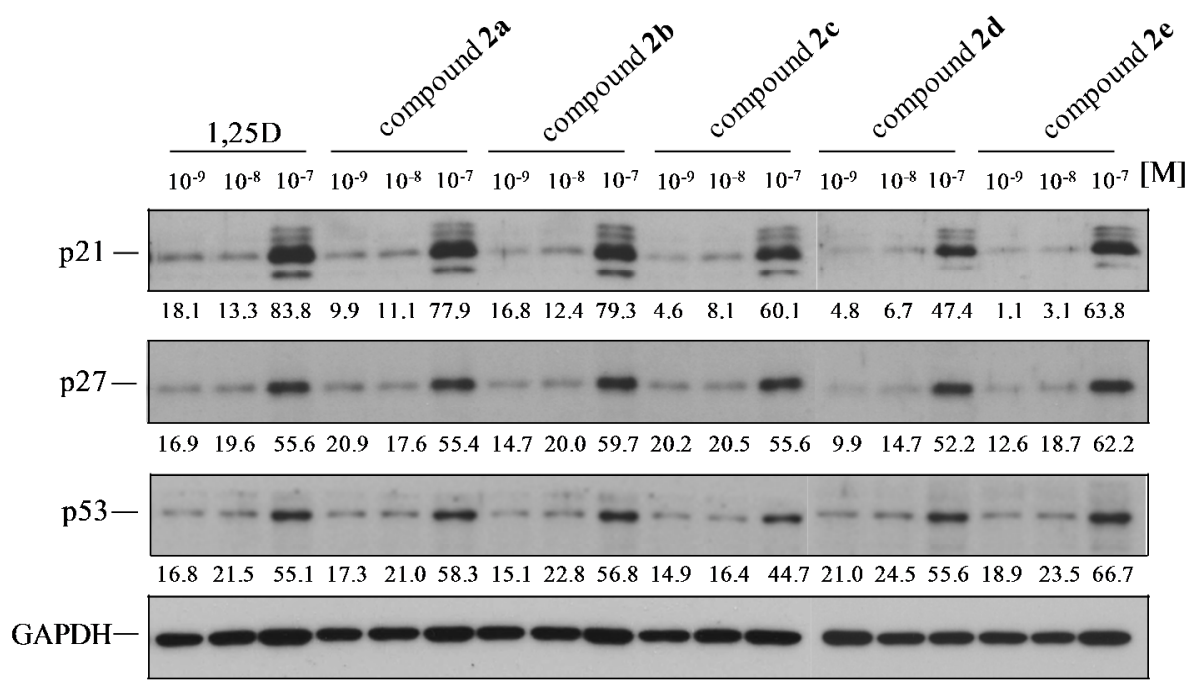




\section{Figure 3.}

a

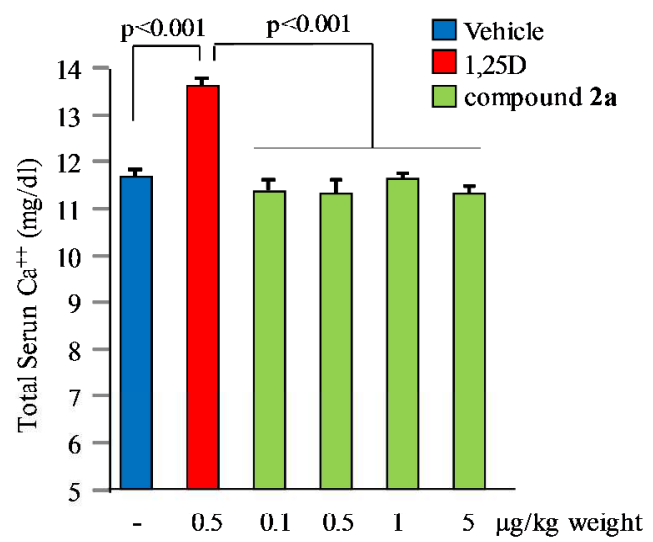

c

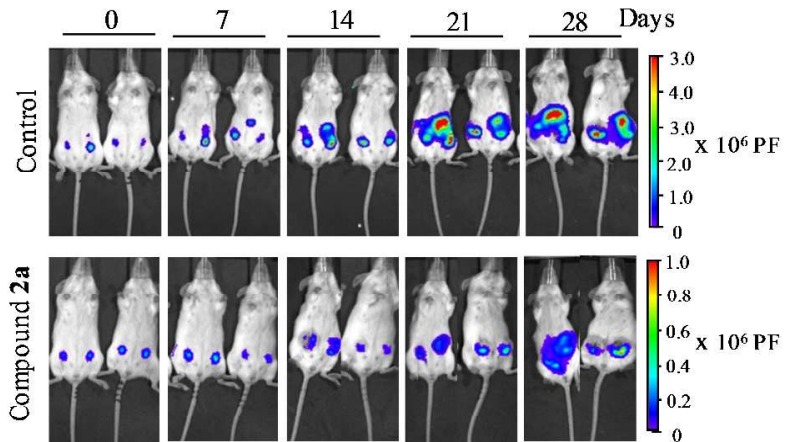

e

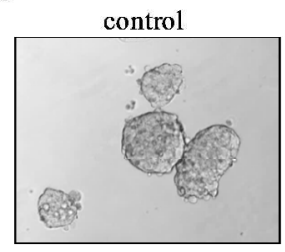

compound 2a 10 [nM]

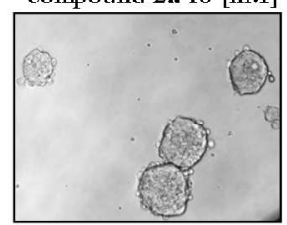

compound 2a $100[\mathrm{nM}]$

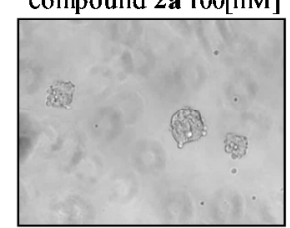

b

d

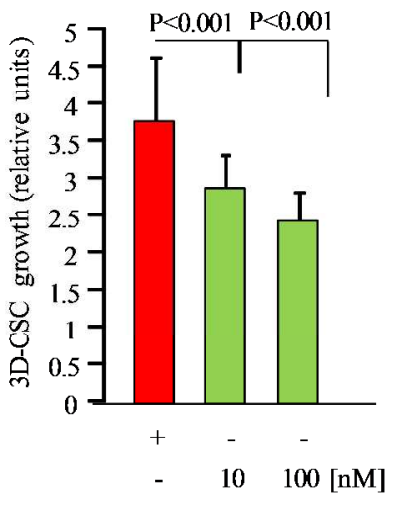

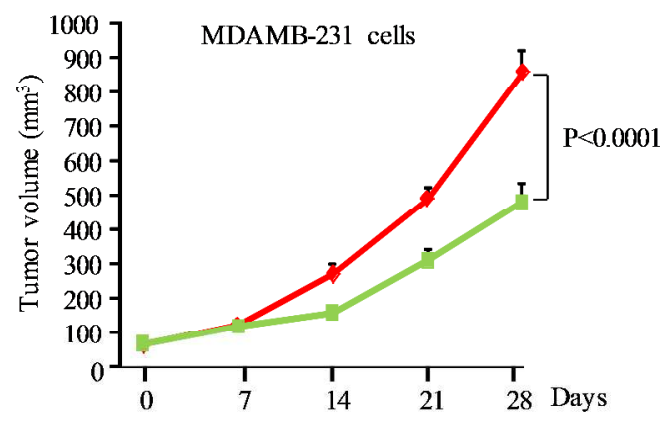

$\rightarrow$ Control

- Compound 2a

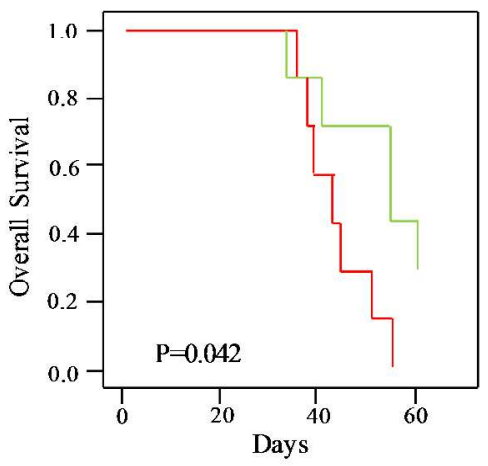

g

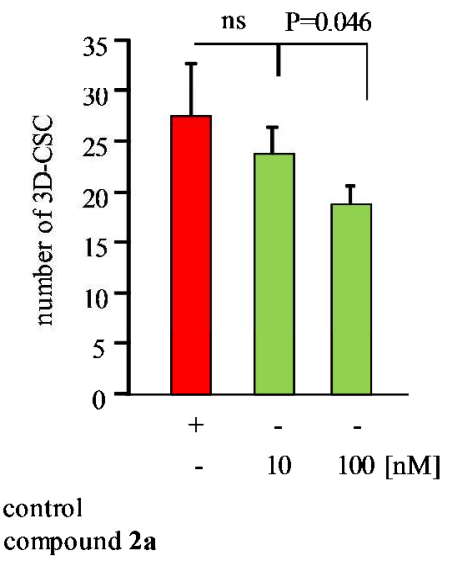




\section{Figure 4.}
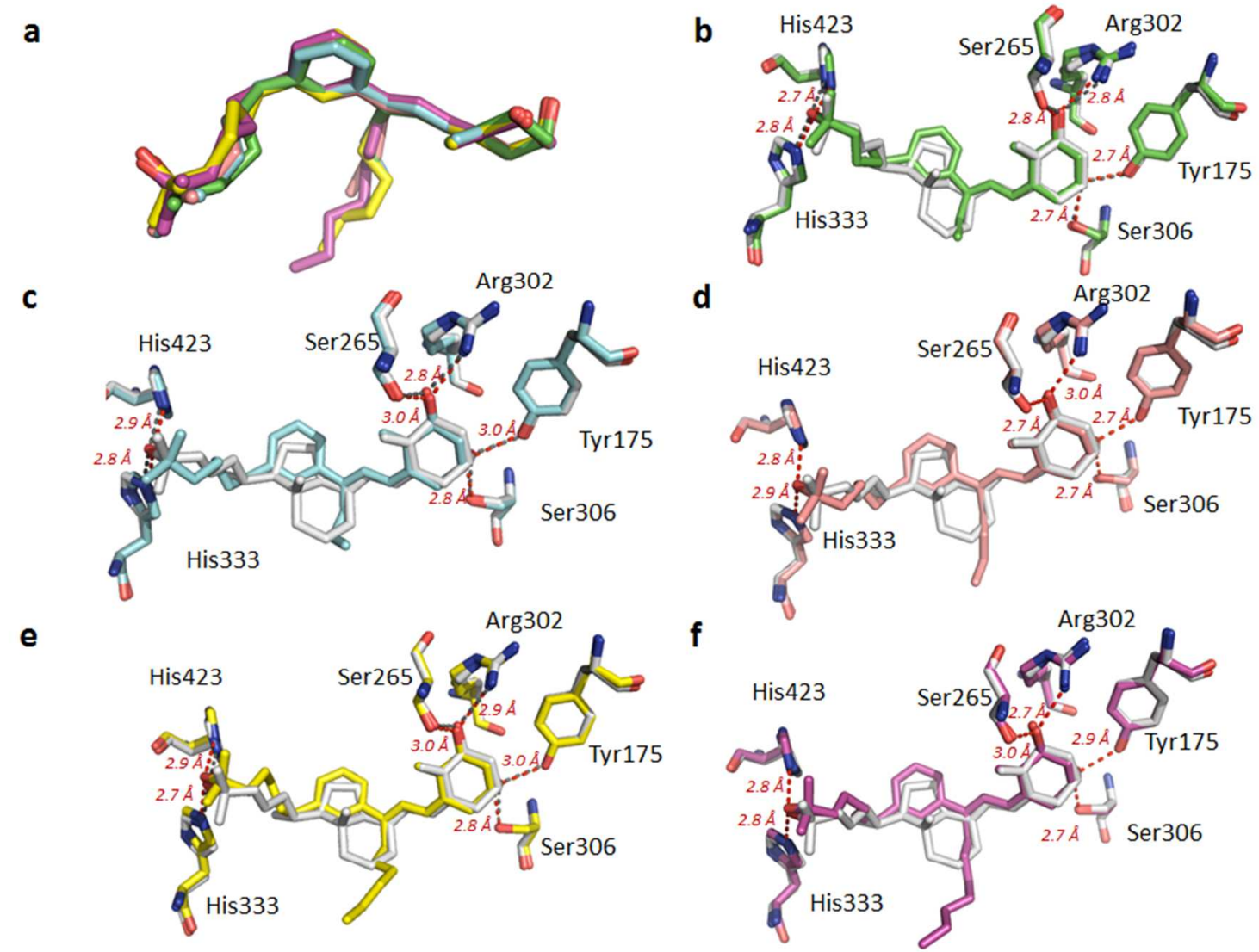

d

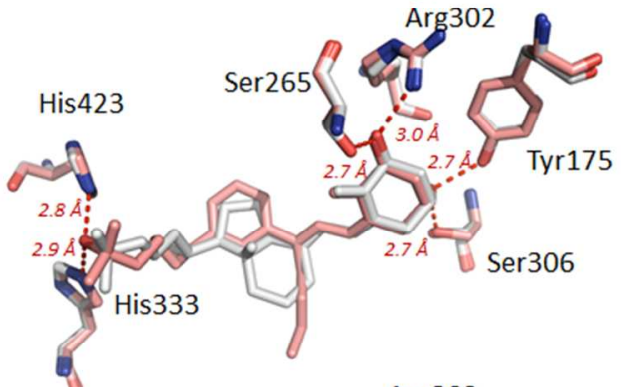


Figure 5.

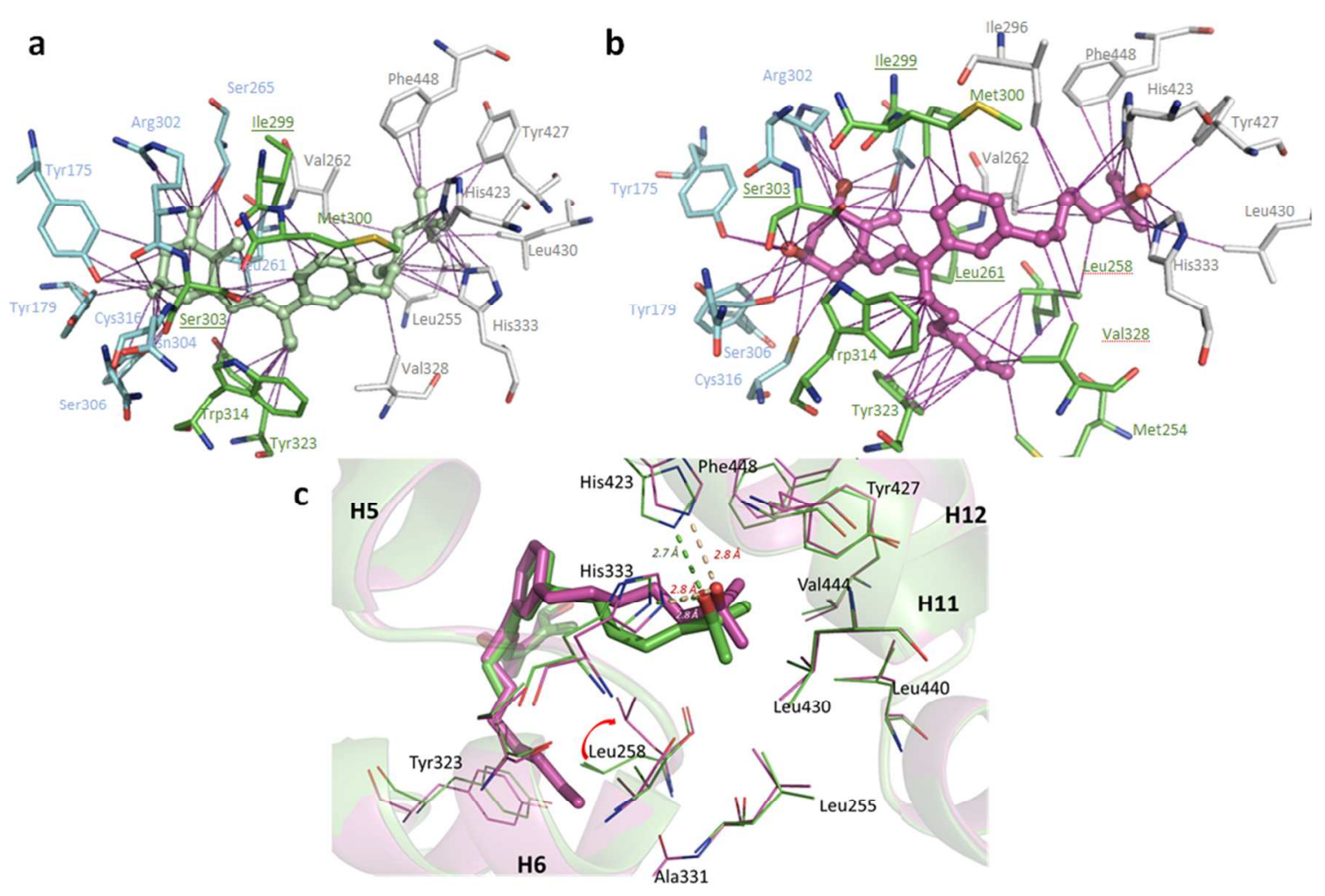

ACS Paragon Plus Environment 
Table 1.

\begin{tabular}{|c|c|c|c|c|c|c|c|}
\hline & \multicolumn{4}{|c|}{ Cellular proliferation } & \multirow{2}{*}{$\begin{array}{c}\text { Transcriptional } \\
\text { activity }\end{array}$} & \multirow[t]{2}{*}{ Calcemia } & \multirow[t]{2}{*}{ VDR binding } \\
\hline & $\begin{array}{c}\text { MCF-7 } \\
(\%)\end{array}$ & $\begin{array}{c}\text { PC-3 } \\
(\%)\end{array}$ & $\begin{array}{c}\text { SKOV-3 } \\
(\%)\end{array}$ & $\begin{array}{c}\mathrm{HaCaT} \\
(\%)\end{array}$ & & & \\
\hline & $2 D-3 D$ & $2 \mathrm{D}$ & $2 \mathrm{D}$ & $2 \mathrm{D}$ & $\mathrm{EC}_{50} \mathrm{M}$ range $(\%)$ & $\mathrm{mg} / \mathrm{dl}(\%)$ & $\mathrm{IC}_{50} \mathrm{M}$ range (\%) \\
\hline $1,25 \mathrm{D}$ & $66 \pm 2.3-61 \pm 9.6$ & $77 \pm 1.2$ & $78 \pm 2.3$ & $69 \pm 1.5$ & $1.6-2.3 \times 10^{-9}(100)$ & $14.7 \pm 0.5(100)$ & $1.3-2.3 \times 10^{-9}(100)$ \\
\hline $2 a$ & $65 \pm 2.4-69 \pm 10.3$ & $78 \pm 2.4$ & $78 \pm 3.4$ & $68 \pm 1.1$ & $5.6-6.2 \times 10^{-9}(33)$ & $11.8 \pm 1.4(0)$ & $4.5 \times 10^{-9}-1.1 \times 10^{-8}(24)$ \\
\hline $2 \mathbf{b}$ & $69 \pm 2.8-74 \pm 10.3$ & $83 \pm 3.0$ & $82 \pm 2.9$ & $71 \pm 1.3$ & $8.6-9.9 \times 10^{-9}(21)$ & $13.1 \pm 1.2(41)$ & $5.6 \times 10^{-9}-5.5 \times 10^{-8}(10)$ \\
\hline $2 c$ & $74 \pm 2.4-84 \pm 8.2$ & $84 \pm 5.6$ & $81 \pm 5.3$ & $71 \pm 1.0$ & $9.0 \times 10^{-9}-1.1 \times 10^{-8}(19)$ & $12.9 \pm 0.8(34)$ & $1.0-1.8 \times 10^{-8}(12)$ \\
\hline 2d & $78 \pm 2.9-79 \pm 7.5$ & $80 \pm 1.9$ & $76 \pm 0.9$ & $74 \pm 2.1$ & $1.0-1.3 \times 10^{-8}(17)$ & $11.7 \pm 0.8(0)$ & $8.3 \times 10^{-9}-4.0 \times 10^{-8}(9)$ \\
\hline $2 \mathrm{e}$ & $69 \pm 4.4-55 \pm 6.2$ & $79 \pm 3.2$ & $83 \pm 5.6$ & $71 \pm 3.2$ & $2.9-4.0 \times 10^{-8}(5)$ & $10.9 \pm 1.3(0)$ & $3.5 \times 10^{-9}-1.6 \times 10^{-7}(7)$ \\
\hline
\end{tabular}

